\title{
PENGARUH PEMBINAAN ASRAMA TERHADAP PEMBENTUKAN KARAKTER MAHASISWA STT KRISTUS ALFA OMEGA TAHUN AJARAN 2018/2019
}

\author{
Fianus Tandiongan \\ (Dosen Prodi Pendidikan Agama Kristen: fianussalom@yahoo.com)
}

\begin{abstract}
When humans pray it will have an impact on changes in their character, including changes in behavior, and reflecting the character of Christ in his life. When humans have a change in character that means he has love in his life that affects himself and others. Evidence of love that is possessed by humans through the life of prayer for changes in their character, that is, with humans, likes to help their fellow students. Have mercy on people who need help when other people have trouble because when humans have had a change of character it will be able to be seen once from their daily lives and humans always have positive thoughts because humans know that God is the source of inner strength his life. This study uses a quantitative method of correlational description of data collection techniques in the form of questionnaires, data analysis techniques using correlational quantitative methods. The results of this study, namely; The first hypothesis "It is suspected that the level of boarding life in the student dormitory of the STT Kristus Alfa Omega Semarang is in the medium category or" 70\% "is rejected because the value obtained is $76.126 \%$. The second hypothesis "It is assumed that the level of character formation of the STT Kristus Alfa Omega Semarang Semarang is in the moderate category or $\leq 75 \%$ " because the value obtained is $81.65 \%$. And the third hypothesis "It is assumed that there is a positive influence and in the medium category between boarding life on the formation of the character of the STT Kristus Alfa Omega Semarang" accepted because the coefficient value obtained is 0.441 which is positive and in the medium category.
\end{abstract}

\section{A. PENDAHULUAN}

Pendidikan pada hakikatnya merupakan usaha sadar untuk mengembangkan kepribadian dan usaha kemampuan manusia, yang diselenggarakan di dalam maupun di luar sekolah atau lembaga pendidikan lain. Dalam mengembangkan ilmu pengetahuan dan teknologi tidak akan berjalan dengan baik tanpa adanya pendidikan yang baik dan efektif, terutama di dalam sistem pendidikan tersebut. Ini sesuai yang tercantum dalam UU RI No. 20 Tahun 2003 tentang Sistem Pendidikan Nasional Bab I Pasal 1 Ayat 1, yang berbunyi:

"Pendidikan adalah usaha sadar dan terencana untuk mewujudkan suasana belajar dan proses pembelajaran agar peserta didik secara aktif mengembangkan potensi dirinya untuk memiliki kekuatan spiritual keagamaan, pengendalian diri, kepribadian, kecerdasan, akhlak mulia, serta keterampilan yang diperlukan dirinya, masyarakat, bangsa, dan negara".

Dari pengertian ini, pendidikan yang dimaksud tentu tidak hanya mencakup pendidikan umum saja, yang bersifat hanya mencerdaskan peserta didik dalam bidang akademis, akan tetapi juga meliputi agama yang secara khusus diarahkan untuk peningkatan potensi spiritual (pengenalan, pemahaman, penanaman nilai-nilai keagamaan dan pengalaman nilai-nilai tersebut yang dapat diaplikasikan dalam kehidupan sehari-hari), membentuk manusia menjadi orang yang beriman dan takut akan Tuhan. Mengacu pada undang-undang tersebut, pendidikan di asrama menjadi salah satu sarana yang efektif untuk menghasilkan orang-orang yang berkarakter dan berkualitas.

\section{${ }^{1}$ UU RI. No. 20 Tahun 2003 Tentang Sistem Pendidikan Nasional (Bandung: Fokus Media,} 2008), 58. 
Sekolah merupakan lembaga pendidikan formal yang mempunyai program yang sistematik dalam melaksanakan bimbingan, pengajaran dan latihan kepada peserta didiknya agar mereka berkembang sesuai dengan potensinya, namun sistem sekolah formal belum mampu sepenuhnya mewujudkan tujuan pendidikan nasional, pasalnya pendidikan keagamaan yang mampu berpengaruh terhadap budi pekerti dan pembinaan karakter hanya diberi waktu sedikit saja minimal dua jam per-minggu.

Pendidikan yang mampu membangun Indonesia adalah pendidikan yang tidak mengedepankan hafalan dan daya ingat mahasiswa terhadap pelajaran, tetapi pendidikan yang berhasil melatih mahasiswa untuk berpikir kritis, cermat, cerdas, dan terampil dalam menghadapi berbagai macam persoalan, bukan hanya soal-soal di sekolah, tetapi juga permasalahan di dunia luar yang tentu saja tidak dapat dihindari. Ada fenomena menarik dari dunia pendidikan yang telah diselenggarakan sejak dulu, baik itu di Indonesia maupun di luar negeri, menjadi suatu fenomena karena sampai saat ini tetap menarik perhatian para pelajar dan orangtua diberbagai tingkatan. Sebenarnya sejak dulu pendidik telah mengenal lembaga/institusi pendidikan yang mengharuskan peserta didik atau mahasiswa/i untuk tinggal dan belajar di dalam area sekolah atau kampus. Untuk mencapai kecerdasan intelektual dan emosional ini, berbagai layanan pendidikan dan metode pembelajaran telah diusahakan oleh seluruh pihak, baik itu guru, orang tua, pembina, dan pemerintah. Salah satu metode yang dianggap tepat untuk melatih karakter dan kemandirian mahasiswa/i adalah diwujudkannya pendidikan berasrama. ${ }^{2}$

Pola pendidikan di ssrama merupakan wadah bagi mahasiswa/i untuk membangun kepribadian menuju kematangan diri sebagai makhluk sosial dan makhluk Tuhan. Pola pendidikan di asrama memiliki peran strategis, berfungsi tidak saja sebagai lingkungan tempat tinggai dan belajar, tetapi juga merupakan lingkungan pergaulan sosial yang membantu membentuk kepribadian para warganya. Pola pendidikan asrama diarahkan mampu memberikan warna positif bagi pembentukan karakter mahasiswa dengan mananamkan nilai-nilai yang luhur di antaranya adalah kepekaan dan kepedulian sosial terhadap lingkungan sekitar. Pola pendidikan di asrama juga diposisikan sebagai tempat melatih kedisiplinan, dan membangun berbagai soft skill yang berguna dalam kehidupan mereka kelak.

Program pendidikan berasrama merupakan program pembinaan akademik dan multibudaya dengan empat pilar pengembangan, yaitu: mental spiritual, wawasan akademik, minat dan bakat, dan sosial budaya. Dalam kehidupan berasrama mahasiswa/i diberikan pembinaan untuk saling peduli, memiliki kemandirian, kedisiplinan, saling menolong dalam kebenaran, dan tidak membeda-bedakan status sosial dan ekonomi dalam pergaulan sehari-hari di asrama. ${ }^{3}$

Kehidupan jaman yang berlangsung cepat seperti sekarang ini berbagai macam perubahan, modernitas ternyata membawa impilikasi negatif dengan adanya ketidakseimbangan antara kebutuhan jasmani dan rohani. Kenyataannya banyak terjadi kerusakan moral di masyarakat akibat kurangnya pendidikan keagamaan baik di rumah maupun di sekolah. Realita kehidupan sosial anak bangsa jaman modern ini banyak menimbulkan kesalahan, keresahan dan ketidaknyamanan di lingkungan masyarakat sekitar. Adapun bentuk dari kerusakan karakter anak remaja, pemuda dan dewasa seperti begal motor, pergaulan bebas, pelecehan seksual, penyalahgunaan narkoba, tawuran, kekerasan, tindakan kriminal,narapidana korupsi dan masih banyak tindakan kejahatan lainnya, Dalam hal ini sudah menjadi pemberitaan di media televisi, radio, surat kabar serta saluran informasi lainnya di media sosial. Kelompok yang melakukan

\footnotetext{
${ }^{2}$ https://dampak-kehidupan-berasrama/. (diakses 1 Maret 2018, pukul 12:15 WIB).

${ }^{3} \mathrm{http}: / /$ staff.uny.ac.id/sites/default/files/pengabdian/drs-suparlan-mpdi/buku-pembinaan-danpengelolaan-ppgt.pdf. (diakses 2 Maret 2018).
} 
aksi kejahatan ini banyak sekali keterlibatan dengan oknum remaja dan pemuda (pelajar mahasiswa/i). ${ }^{4}$

Kenyataan ini membuat orang tua merasa khawatir, dan tidak mudah untuk mencari lingkungan yang baik untuk putra-putrinya, keresahan para orang tua terhadap terhadap kerusakan moral pada kehidupan anak, membuat mereka berpikir untuk menyekolahkan atau menguliahkan anaknya di institusi pendidikan berasrama. Sebagian lagi orang tua memilih anaknya menuntut ilmu di institusi pendidikan berasrama karena menginginkan anaknya memiliki bekal pendidikan kerohanian ataupun perilaku disiplin. Alasan lain tumbuhnya kesadaran orang tua bersama peserta didik itu sendiri yang menginginkan masa depan yang lebih baik sehingga memilih institusi pendidikan kedinasan yang pada umumnya berasrama.

Sekolah Tinggi Teologi Kristus Alfa Omega Semarang (selanjutnya disebut STT $\mathrm{KAO}$ ), salah satu lembaga pendidikan yang menyelenggarakan pendidikan dengan menerapkan pola pendidikan asrama. Semua mahasiswa kelas reguler, selain mahasiswa yang sudah berkeluarga (oleh karena keterbatasan sarana) diwajibkan untuk tinggal di asrama Sekolah Tinggi Teologi Kristus Alfa Omega Semarang. Hal ini dimaksudkan dengan tujuan agar mahasiswa dapat dibentuk menjadi hamba-hamba Tuhan yang tidak hanya memiliki pemahaman firman Tuhan, tetapi juga memiliki karakter yang baik sebagaimana visi Sekolah Tinggi Teologi Kristus Alfa Omega Semarang yaitu: Menjadi Sekolah Tinggi Teologi yang unggul dan alkitabiah, berkarakter Kristus yang bercirikan Pentakosta Kharismatik.

\section{B. METODOLOGI}

Metodologi yang digunakan adalah kuantitatif deskriptif korelasional. Menurut Sumanto, penelitian deskriptif korelasional berkaitan dengan pengumpulan data untuk memberikan gambaran atau penegasan sutau konsep atau gejala, juga menjawab pertanyaanpertanyaan sehubungan dengan status subjek penelitian pada saat ini dengan tujuan menentukan ada tidaknya hubungan dan seberapa jauh suatu hubungan antara dua variabel (yang dapat diukur) atau lebih. ${ }^{5}$

\section{PEMBAHASAN}

\section{Pembinaan Kehidupan Berasrama}

a. Tujuan Pembinaan

Pembinaan berasal dari kata "bina" yang merupakan proses, cara perbuatan, mendirikan, membina, membangun, pembaharuan, penyempurnaan usaha, tindakan, dan kegiatan yang dilakukan secara efisien dan efektif untuk memperoleh hasil yang lebih baik. ${ }^{6}$ Menurut Arifin, pembinaan yaitu usaha menusia secara sadar untuk membimbing dan mengarahkan kepribadian serta kemampuan anak, baik dalam pendidikan formal maupun non formal. ${ }^{7}$ Sedangkan menurut Manguhardjana, pembinaan adalah suatu proses belajar dengan melepas hal-hal yang sudah dimiliki dan mempelajari hal-hal yang baru yang belum dimiliki,

\footnotetext{
${ }^{4}$ http://www.rifalnurkholiq.com/2015/10/laporan-studi-kasus-kenakalan-remaja.html. (diakses 2 Maret 2018).

${ }^{5}$ Sumanto, Pembasan Terpadu Statistika dan Metodologi Riset, (Yogyakarta: Andi, 2002), 13. WIB).

${ }^{6} \mathrm{http}: / /$ www.kbbi.web.id/indek.php?w=program. (diakses Jumat 10 maret 2017, pukul 10:13

${ }^{7}$ H. M Arifin, Hubungan Timbal Balik Pendidikan Agama (Jakarta: Bulan Bintang, 1976), 30.
} 
dengan tujuan membantu orang yang menjalaninya untuk membetukkan dan mengembangkan pengetahuan, kecakapan baru untuk mencapai tujuan hidup serta kerja yang sedang dijalaninya secara lebih efektif. ${ }^{8}$

Berdasarkan pengertian di atas dapat disimpulkan bahwa pembinaan yang dimaksudkan lebih mengarah pembinaan karakter yang merupakan suatu usaha yang dilakukan dengan sadar, sungguh-sungguh terencana dan konsisten dalam pembentukan karakter mulai dengan membimbing, mengarahkan dan mengembangkan pengetahuan, kecakapan dan pengalaman siswa selama menuntut ilmu sehingga mereka mengerti, memahami dan menerapkannya dalam kehidupan bermasyarakat.

Adapun tujuan utama dari pembinaan di asrama adalah untuk membentuk dan mengembangkan siswa supaya memiliki:

1) Kepribadian yang bertakwa, bermoral luhur, jujur, tangguh, dan disiplin.

2) Kecerdasan dan prestasi.

3) Kesehatan jasmani dan rohani.

4) Kepedulian, kepekaan, dan kemampuan beradaptasi dengan lingkungan yang majemuk.

5) Jiwa menghargai dan mengembangkan seni, budaya, dan keterampilan.

6) Kemandirian, kreativitas, inovasi, tanggung jawab, dan jiwa antisipatif. ${ }^{9}$

Undang-undang Peraturan Menteri Pendidikan Nasional No. 38 Tahun 2008 pasal 1 juga telah menimbang dan menetapkan ketentuan dalam hal tujuan pembinaan dan sasaran pembinaan kesiswaan, yaitu:

1) Mengembangkan potensi siswa secara optimal dan terpadu yang meliputi bakat, minat dan kreativitas.

2) Menetapkan kepribadian siswa untuk mewujudkan ketahanan sekolah sebagai lingkungan pendidikan sehingga terhindar dari usaha dan pengaruh negatif yang betentangan dengan tujuan pendidikan.

3) Mengaktualisasikan potensi siswa dalam mencapai unggulan bakat dan minat serta menyiapkan siswa agar menjadi warga masyarakat yang berakhlak mulia, demokratis, menghormati hak-hak asasi manusia dalam rangka mewujudkan masyarakat madani (civil society).

4) Sasaran pembinaan kesiswaan itu meliputi siswa Taman Kanak-kanak (TK), Taman Kanak-kanak luar biasa (TKLB), Sekolah Dasar (SD), Sekolah Dasar Luar Biasa (SDLB), Sekolah Menengah Pertama (SMP), Sekolah Menengah Pertama Luar Biasa (SMPLB), Sekolah Menengah Atas (SMA), Sekolah Menengah Atas Luar Biasa (SMALB), dan Sekolah Menengah Kejuruan (SMK). ${ }^{10}$

Dengan demikian dapat disimpulkan bahwa pembinaan di asrama adalah suatu hal yang sangat penting, karena siswa merupakan generasi yang sedang dalam proses pendidikan yang tentunya sangat perlu untuk dipersiapkan menjadi generasi penerus bangsa yang berkualiatas dalam ilmu pengetahuan dan teknologi serta memiliki kehidupan sosial yang berkarakter religi dan budaya yang tinggi sehingga tanggap dan tangguh serta mampu terlibat dalam seluruh aspek kehidupan. Untuk mencapai peraturan yang telah ditetapkan oleh menteri pendidikan nasional tersebut maka diperlukan ketegasan dan komitmen bagi setiap guru

\footnotetext{
${ }^{8}$ Mangunharjana, Pembinaan: arti dan metodeknya (Yogyakarta: Kanisius, 1986), 12.

${ }^{9}$ TIM PPGT, Pembinaan dan Pengelolaan Mahasiwa Berasrama, (Yogyakarta: uny Press,
} 2013), 2.

${ }^{10} \mathrm{http} / / /$ kelembagaan.ristekdikti.go.id/wpcontent/uploads/2016/12/permendiknas_39_2008_ttg_ kesiswaan.pdf (diakses 22 Febuari 2017, pukul 11:45 WIB). 
maupun para pembina asrama yang telah dipercayakan untuk menerapkan serta menjalankan peraturan yang ada.

\section{b. Hakikat dan Fungsi Asrama}

Penghuni asrama adalah individu-individu peserta didik yang berasal dari latar belakang yang berbeda-beda, baik dari segi pendidikan orang tua, status sosial ekonomi, dan adat istiadat.

\section{1) Hakikat Asrama}

Hakikat kehidupan asrama bukan sekadar pembentukan kebiasaan (habit formation) dan kesan-kesan sensoris, namun suatu proses pembentukan nilai. Dengan kata lain, hidup di asrama pada hakikatnya adalah pembentukan nilai-nilai hidup, yakni: nilai keagamaan, nilai kebenaran, nilai kebersamaan (sosial), nilai keindahan, nilai ekonomis dan sebagainya. Oleh karena itu, dalam kehidupan di asrama diperlukan adanya saling menghargai, saling mengakui, saling menerima dan memberi, dan saling mengembangkan diri sendiri. ${ }^{11}$

\section{2) Fungsi Asrama}

Asrama sekolah harus dapat menciptakan suasana "home". Maksudnya kultur kehidupan di asrama harus berisi suasana "rumah" dalam pengertian sebagai berikut: lingkungan penuh kasih sayang setiap siswa jauh dari suasana perselisihan. Selain itu merupakan tempat bagi siswa untuk dilibatkan dalam berbagai kegiatan. Asrama juga memperhatikan pola makan siswa tiga kali sehari sekenyang-kenyangnya. Kehidupan asrama harus dapat menjadi laboratorium sosiologis, di mana hubungan-hubungan antara sesama merupakan kunci utama. Artinya dalam kehidupan asrama di sekolah harus diusahakan berbagai pengalaman belajar (learning-activity) sebagai persiapan untuk hidup di masyarakat. ${ }^{12}$

Selaras dengan hakikat dan fungsi kehidupan asrama maka secara umum tujuan diselenggarakannya sekolah berasrama adalah untuk menunjang keberhasilan pencapaian tujuan pendidikan di sekolah. Sedangkan menurut Kusmintardjo, secara khusus tujuan penyelenggaraan asrama adalah sebagai berikut: ${ }^{13}$

1) Memberikan bimbingan kepada siswa (penghuni asrama sekolah) dan menanamkan rasa disiplin pada diri siswa.

2) Membiasakan para siswa untuk mencintai belajar bersama-sama dengan teman sebayanya.

3) Membantu siswa agar dapat menyesuaikan diri pada kehidupan sosial dalam lingkungan sebaya.

4) Membantu siswa dalam proses pengambangan nilai-nilai kecerdasan dan keterampilan.

5) Membantu memberikan tempat penginapan bagi para siswa yang rumahnya jauh dari sekolah.

\footnotetext{
${ }^{11}$ Kusmintardjo, Pengelolaan Layanan Khusus di Sekolah (Malang: IKIP 1992), 4.

${ }^{12}$ Kusmintardjo, Penyelengaraan Pelatihan Dengan Sistem Asrama (Boarding School) (Malang: FIP UM 1992), 4.

${ }^{13}$ Ibid., 6 .
} 
c. Bentuk-Bentuk Pembinaan Asrama

Bentuk pembinaan yang dilakukan para pembina terhadap anak asuh meliputi beberapa aspek:

1) Pembinaan untuk Menunjang Pendidikan Formal (Sekolah)

Pendidikan formal yang dimaksudkan di sini adalah pendidikan yang dilakukan di sekolah. Siswa tidak hanya mendapatkan pendidikan serta wawasan di asrama saja melainkan juga di sekolah, pembinaan dimaksudkan untuk melaksanakan program bimbingan, pengajaran, dan latihan dalam rangka membantu siswa agar mampu mengembangkan potensinya baik yang menyangkut aspek moral spritual, intelektual, emosional, maupun sosial. Dalam program, penunjang pendidikan ini berbentuk seperti ada jam khusus untuk setiap siswa harus belajar agar mempunyai kesempatan untuk menyelesaikan setiap tugas-tugas dari sekolah dan dengan belajar mandiri.

\section{2) Pembinaan bagi Pembentukan Kelompok Belajar}

Kelompok belajar adalah sebuah model pembelajaran di mana peserta didik belajar bekerja sama dalam sebuah kelompok untuk menyelesaikan tugas belajar. Menurut Modjiono metode kelompok belajar dapat diartikan sebagai format belajar mengajar yang menitikberatkan kepada interaksi anggota yang satu dengan anggota yang lain dalam suatu kelompok guna menyelesaikan tugas-tugas belajar secara bersama-sama. Jadi, kelompok belajar adalah membangun interaksi dalam kelompok dengan tujuan untuk memecahkan permasalahan yang ada. ${ }^{14}$

Hal ini bertujuan agar siswa dapat mengulang pelajaran yang telah diberikan di sekolah. Dalam kelompok ini diharapkan agar siswa dapat saling membantu dalam mengembangkan cara berpikir kritis dalam memecahkan masalah, mengembangkan kemampuan bersosialisasi dan komunikasi, meninggikan rasa percaya diri terhadap kemampuan siswa. Selain itu, belajar kelompok juga bertujuan agar siswa dapat memahami dan menghargai orang lain.

\section{3) Pembinaan Menyangkut Aspek Mental dan Keagamaan}

Kesehatan mental adalah ilmu yang meliputi sistem tentang prinsip-prinsip, peraturan serta prosedur-prosedur untuk mempertinggi kesehatan rohani. ${ }^{15}$ Orang sehat mentalnya ialah orang yang dalam rohani atau dalam dirinya selalu merasa tenang, aman dan tenteram. ${ }^{16}$ Hubungan antara kejiwaan dan agama dalam kaitannya dengan hubungan antara agama sebagai keyakinan dan kesehatan jiwa, terletak pada sikap penyerahan diri seseorang terhadap suatu kekuasaan Yang Maha Tinggi. Pembinaan yang dilakukan dalam kehidupan berasrama, tujuannya untuk terbentuknya mental dan keagamaan setiap siswa, maka ibadah diwajibkan kepada setiap anak agar mereka tidak hanya cerdas dalam hal akademis, tetapi mereka memiliki kualitas dalam kehidupan rohani, dan bimbingan rohani tersebut disesuaikan dengan iman dan kepercayaan mereka masing-masing.

\footnotetext{
${ }^{14}$ Modjiono, Belajar dan Pembelajaran (Jakarta: Rineka Cipta, 1992), 61.

${ }^{15}$ M. Buchori, Psikologi Pendidikan (Jakarta: Aksara Baru 1982), 13.

${ }^{16}$ Ibid., 5.
} 
4) Pembinaan Menyangkut Aspek Sikap Sosial

Perilaku sosial adalah suasana saling ketergantungan yang merupakan keharusan untuk menjamin keberadaan manusia. ${ }^{17}$ Sebagai bukti bahwa manusia dalam memenuhi kebutuhan hidup sebagai pribadi tidak dapat melakukan sendiri dan memerlukan bantuan dari orang lain. Artinya bahwa kelangsungan hidup manusia berlangsung dalam suasana saling mendukung dalam kebersamaan. Sesungguhnya yang menjadi dasarnya adalah manusia makhluk sosial. ${ }^{18}$ Asrama memberi bimbingan dan memonitor sikap siswa terhadap teman-temannya dalam kehidupan berasrama dan sekolah. Untuk itu pembina asrama memberikan pengertian kepada setiap siswa bahwa dalam kehidupan ini manusia saling membutuhkan satu sama lain. Asrama menciptakan kondisi atau peraturan yang membawa siswa harus bersikap sosial kepada teman-temannya baik di asrama maupun kepada semua orang. Kemudian pembina sebagai pengganti orang tua siswa harus dapat membawa anak dalam satu situasi yang berupa hubungan antara anak dengan orang tua, sehingga dalam diri anak timbul rasa hormat, sayang dan cinta pada orang yang lebih tua.

\section{5) Pembinaan Menyangkut Aspek Fisik dan Kesehatan}

Menurut Sugiyanto kemampuan fisik adalah kemampuan memfungsikan organ-organ tubuh dalam melakukan aktivitas fisik. ${ }^{19}$ Kemampuan fisik sangat penting untuk mendukung mengembangkan aktivitas psikomotorik. Gerakan yang terampil dapat dilakukan apabila kemampuan fisiknya memadai. Menurut Sajoto kondisi fisik adalah satu kesatuan utuh dari komponen-komponen yang tidak dapat dipisahkan begitu saja, baik peningkatan maupun pemeliharaan. Artinya bahwa di dalam usaha peningkatan kondisi fisik maka seluruh komponen tersebut harus berkembang. ${ }^{20}$

Berdasarkan pendapat di atas dapat disimpulkan bahwa kondisi fisik dan kesehatan merupakan salah satu fondasi terwujudnya prestasi siswa yang maksimal, maka dalam pencapaiannya pembina harus memperhatikan fisik dan kesehatan siswa. Dalam hal ini yang dapat dilakukan oleh pembina melalui memberikan menu makanan yang mengandung gizi yang cukup untuk menjamin kesehatan siswa, memberikan pertolongan pengobatan, apabila siswa mengalami sakit dan menyediakan obat-obatan untuk persediaan bagi setiap siswa ketika sakit.

\section{Pembentukan Karakter}

Menurut Kamus Umum Besar Bahasa Indonesia, karakter diartikan sebagai tabiat; watak; sifat-sifat kejiwaan akhlak atau budi pekerti yang membedakan seseorang dengan yang lain. ${ }^{21}$ Wyne menyatakan pendapatnya bahwa karakter berasal dari bahasa Yunani "karasso" yang berarti "to mark" yaitu "menandai atau mengukir, yang memfokuskan bagaimana mengaplikasikan nilai kebaikan dalam bentuk tindakan atau tingkah laku". Istilah karakter erat kaitannya dengan personality (kepribadian) seseorang. ${ }^{22}$

\footnotetext{
${ }^{17}$ Rusli Ibrahim, Landasan Psikologi Pendidikan Jasmani Di Sekolah (Jakarta: Balai Pusataka 2001), 58 .

${ }^{18}$ W.A. Gerungan, Psikkologi Sosial (Bandung: Eresoo. 1978), 28.

${ }^{19}$ Menurut Sugiyanto, Kamus Besar Bahasa Indonesia (Jakarta: Balai Pustaka1996), 221.

${ }^{20}$ Mochamad Sajoto Pembinaan Kondisi Fisik Dalam Olahraga, (Jakarta: Pustaka Kartini1995:

$8-9)$.

${ }^{21}$ Irna M. Lapindus, Kamus Umum Bahasa Indonesia (Jakarta: Balai Pustaka, 1982), 445.

${ }^{22}$ http://pustaka.pandani.web.id/2013/03/ pengertian-karakter.html, (diakses 3 Maret 2017, 2:06 
Sedangkan dalam Kamus Sosiologi, karakter diartikan sebagai ciri khusus dari struktur dasar kepribadian seseorang (karakter, watak). ${ }^{23}$

Griek, seperti yang dikutip Zubaedi mengemukakan bahwa karakter dapat didefinisikan sebagai panduan dari pada segala tabiat manusia yang bersifat tetap, sehingga menjadi tanda yang khusus untuk membedakan orang yang satu dengan yang lain. ${ }^{24}$

Suyanto dan Muslich menyatakan bahwa karakter yaitu cara cara berpikir dan berperilaku seseorang yang menjadi ciri khas dari tiap individu untuk hidup dan bekerjasama, baik dalam keluarga, masyarakat dan negara. ${ }^{25}$

Berdasarkan pembahasan di atas dapat ditegaskan bahwa karakter merupakan perilaku manusia yang membedakan dengan sesamanya, namun pada intinya saling berhubungan dengan Tuhan, diri sendiri, sesama manusia, lingkungan dan kebangsaan yang terwujud dalam pikiran, sikap perasaan, perkataan dan perbuatan berdasarkan norma agama, hukum, tata krama, budaya dan adat istiadat.

Dengan mengetahui adanya karakter (watak, sifat, tabiat,) seseorang dapat memperkirakan reaksi-reaksi dirinya terhadap berbagai fenomena yang muncul dalam diri ataupun hubungannya dengan orang lain, dalam berbagai keadaan serta bagaimana mengendalikannya. Karakter dapat ditemukan dalam sikap-sikap sesorang, terhadap dirinya, terhadap orang lain, terhadap tugas-tugas yang dipercayakan padanya dan situasi-situasi yang lainnya.

a. Landasan Alkitab Mengenai Pembentukan Karakter

Beberapa karakter Kristus tertulis dalam kebenaran Firman Tuhan yang dapat dikembangkan dan ditampilkan oleh setiap orang percaya, yaitu:

1) Kasih

Kasih begitu penting karena merefleksikan kasih Allah dalam Yesus Kristus. Hal ini tidak hanya ditunjukkan oleh ayat yang dengan merujuk kepada kasih Allah atau kasih Kristus, mendorong orang percaya untuk saling mengasihi (Flp. 2:1-2,5; Ef. 5:2, 25). ${ }^{26}$ Perintah Kristus melalui para rasul-Nya adalah bahwa sebagai anak-anak Allah harus saling mendahului dalam memberi hormat, menerima orang lain seperti Kristus telah menerima umat-Nya, mengasihi dengan tulus dan dengan kasih yang berasal dari hati yang terdalam. ${ }^{27}$ Kasih itu diekspresikan oleh perbuatan-perbuatan yang baik dan kasih itu telah terungkapkan dengan sangat baik dalam karakter, sifat dan perbuatan Allah sendiri. Allah itu kasih (1 Yoh. $4: 8,16) .{ }^{28}$ Kasih merupakan penyajian akhir dari karakter Allah. ${ }^{29}$

2) Kesabaran

Kesabaran adalah suatu penerimaan yang timbul karena perbuatan orang lain terhadap kita. Kesabaran merupakan salah satu atribut Allah sebutkan kepada Musa ketika Ia

\footnotetext{
${ }^{23}$ Soejono Soekanto, Kamus Sosiologi (Jakarta: Rajawali Pres, 1993), 74.

${ }^{24}$ Zubaedi, Desain Pendidikan Karakter Konsepsi dan Aplikasinya daam Dunia Pendidikan (Jakarta: Kencana, 2012), 9.

${ }^{25}$ Masnur Muslich, Pendidikan Karakter Menjawan Tantangan Krisis Multimdimensional (Jakarta: Bumi Akasra, 2011), 70.

${ }^{26}$ Herman Ridderbos, Paulus Pemikiran Utama Theologinya (Surabaya: Penerbit Momentum, 2010), 308 .

${ }^{27}$ John Kingsley Alley, Holy Community, (Jakarta: Metanoia Publishing, 2010), 55.

${ }^{28}$ Joyce Meyer, The Power of Simple Prayer (Jakarta: Imanuel, 2010), 201.

${ }^{29}$ Brian J. Bailey, Roh Kudus Sang Penghibur, (Jakarta: Penerbit Voice of Hope, 2015), 211.
} 
menampakkan diri di atas bukit". ${ }^{30}$ Kesabaran adalah ketekunan dan ketabahan yang mengalahkan segala yang berkenaan dengan manusia, karena kesabaran mengalahkan roh seseorang. Amsal 25:15 mencatat "dengan kesabaran seorang penguasa dapat diyakinkan". Kesabaran itu lebih banyak berurusan dengan orang daripada dengan situasi-situasi. Ada sebuah perbedaan antara ketekunan (patience) dan kesabaran (longsuffering). Ketekunan berarti "ketabahan di dalam menanggung ujian-ujian dan keadaan-keadaan". Sebaliknya, kesabaran berarti "menderita bersama orang-orang untuk jangka waktu yang sangat, sangat lama". ${ }^{31}$ Jadi setiap orang percaya harus memiliki karakter seperti Tuhan Yesus yang penuh kesabaran.

\section{3) Kebaikan}

Ketika seseorang disebut baik di dalam Alkitab, itu berarti mereka baik secara moral. Defenisi Alkitab tentang kebaikan Allah adalah "tidak ada keinginan untuk berbuat kejahatan". ${ }^{32}$ Kebaikan adalah kemuliaan Allah. Kemulian Allah sesungguhnya merupakan karakter dasar-Nya. Kebaikan terpancar dari-Nya sama seperti kemuliaan dan terang terpancar dari-Nya. ${ }^{33}$

Seorang yang baik melakukan apa yang benar, tanpa mempedulikan reaksi orang lain. Karena itu, dapat dilihat bahwa kemurahan tidak dipersamakan dengan kebaikan. Kebaikan mengadakan perbedaan yang jelas antara orang benar dan orang yang tidak benar; yang kudus dan yang cemar. Kebaikan tidak akan membiarkan kita berkompromi dalam bidang apa pun. Kebaikan mengandung arti jalan kehidupan yang terpisah. Kemurahan itu berarti bersikap baik terhadap musuh, tetapi kebaikan tidak bertoleransi terhadap kejahatan di dalam diri musuh. Kebaikan menurut Samuel untuk menolak Saul; dan Allah memerintahkan agar Samuel berhenti meratapinya (1 Sam. 16:1). ${ }^{34}$

\section{4) Kesetiaan}

Kesetiaan merupakan bagian dari iman; dan iman adalah percaya serta yakin akan kesetiaan Allah. ${ }^{35}$ Kesetiaan itu berarti setia dalam menyelesaikan tugas yang Allah berikan kepada umat-Nya. Itu berarti bahwa perkataan dan janji-janji itu benar, dan umat-Nya dapat diandalkan, dipercaya, dan setia. ${ }^{36}$ Orang yang setia adalah orang yang dapat diandalkan karena ia mempunyai catatan kehidupan yang selalu melakukan segala yang dipercayakan kepadanya. Kesetian adalah ciri-ciri dari hamba Tuhan yang sejati. Abrahan disebut sebagai orang yang setia (Neh. 9:8)" ${ }^{37}$ Orang percaya harus setia untuk melakukan segala hal yang Tuhan tugaskan, baik itu kecil atau besar. Demikian halnya sebagai guru maupun pembina yang dipercayakan untuk mendidik dan membina setiap siswa harus setia dalam mejalankan serta tanggung jawab dengan baik.

\footnotetext{
${ }^{30}$ C. Marvin Pate, Teologi Paulus Tentang Kristologi, Seteriologi, Antropologi, Pneumatologi, Eklesiologi, Eskatologi (Malang: Penerbit Gandum Mas, 2004), 178.

${ }^{31}$ Brian J. Bailey, 252.

${ }^{32}$ Brian J. Bailey, 260.

${ }^{33}$ Ibid, 261.

${ }^{34}$ Brian J. Bailey, 262.

${ }^{35}$ Ibid.

${ }^{36} \mathrm{Ibid}, 263$

${ }^{37}$ Ibid, 265 .
} 


\section{5) Penguasaan Diri}

Penguasaan diri berarti memiliki penguasaan atas keinginan-keinginan dan akan kecintaan seseorang terhadap kesenangan-kesenangan. Ini berlaku untuk setiap orang di dalam kehidupannya, bukan hanya dalam hal minuman keras dan makanan saja. Untuk alasan ini, tanpa penguasaan diri maka tidak akan berhasil di dalam hidup kekristenan. Jadi setiap guru maupun pembina yang memiliki tugas dan tanggung jawab harus dapat menguasai diri dalam bertindak dan berperilaku supaya menjadi teladan yang memotivasi siswa untuk rindu memiliki karakter yang juga dapat menguasai diri secara pribadi.

Pembentukan karakter juga telah menjadi salah satu tujuan pendidikan nasional. Pasal 1 Undang-Undang Sistem Pendidikan Nasional Nomor 20 Tahun 2003 menyebutkan diantara tujuan pendidikan nasional adalah mengembangkan potensi peserta didik untuk mempunyai kecerdasan, kepribadian, dan karakter mulia. ${ }^{38}$ Pemerintah menekankan betapa pentingnya pembentukan karakter dan kesuksesan pendidikan karakter, pada pasal 13 ayat 1 juga menyatakan bahwa jalur pendidikan terdiri dari pendidikan formal, nonformal, dan informal.

Ryan dan Lickona seperti dikutip Lestari mengungkapkan bahwa "nilai dasar yang menjadi landasan dalam membangun karakter adalah hormat (respect). Hormat tersebut mencakup respect pada diri sendiri, orang, semua bentuk kehidupan maupun lingkungan yang mempertahankannya. Dengan memiliki hormat, maka individu memandang dirinya maupun orang lain sebagai sesuatu yang berharga dan memiliki hak derajat. ${ }^{39}$

Unsur terpenting dalam pembentukan karakter adalah pikiran, karena pikiran yang di dalamnya terdapat seluruh program yang terbentuk dari pengalaman hidupnya, merupakan pelopor segalanya. ${ }^{40}$ Program ini kemudian membentuk sistem kepercayaan yang akhir dapat membentuk pola pikir yang bisa mempengaruhi perilaku seseorang. Jika program yang tertanam tersebut sesuai dengan prinsip-prinsip kebenaran universal, maka perilakunya berjalan selaras dengan etika dan moral yang berlaku dalam kehidupannya.

Masing-masing jalur pendidikan diharapkan dapat saling melengkapi dan memperkaya satu sama lain. Jenjang pendidikan informal terdiri dari pendidikan dasar, pendidikan menengah, pendidikan tinggi (ps. 14), pendidikan non formal terdiri dari lembaga kursus, lembaga pelatihan, kelompok belajar, pusat kegiatan belajar masyarakat, dan majelis taklim, serta satuan pendidikan yang sejenis (ps. 26 ay. 4). ${ }^{41}$

Wibowo menuliskan dalam bukunya, Strategi Membangun Karakter Bangsa Berpradaban, pemerintah Amerika Serikat menekan bahwa pendidikan berperan penting dalam pembentukan karakter bagi masyarakatnya. Bahkan di Dapartemen Tenaga Kerja Amerika Serikat pada tahun 1991, merekomendasikan pentingnya internalisasi pendidikan karakter di sekolah-sekolah. Itulah sebabnya mereka mempunyai kepentingan besar dalam bidang pendidikan, yaitu untuk mempersiapkan warga negaranya memiliki karakter yang kuat demi mencapai tujuan kehidupan berbangsa dan bernegara. ${ }^{42}$

Berdasarkan setiap pandangan di atas dapat disimpulkan bahwa pendidikan berperan penting dalam mengupayakan pembentukan karakter anak selama mengikuti proses

\footnotetext{
${ }^{38}$ Undang-Undang Republik Indonesai Nomor 20 tahun 2003 tentang Sistem Pendidkan Nasional (Jakarta: Sinar Grafirka 2003), 8.

${ }^{39}$ Sri Lestari, Psikologi Keluarga Penanaman Niliai dan Penanganan Konflik dalam Keluarga (Jakarta: Kencana, 2013), 96.

${ }^{40}$ Thomas Lickona, Charater Matter (Jakarta: Bumi Aksara, 2012), 50.

${ }^{41}$ Ibid., 10.

${ }^{42}$ Agus Wibowo, Pendidikan Karakter:Strategi Membangun Karakter Bangsa Berpradaban (Yogyakarta: Pustaka Pelajar 2012), 53.
} 
pembelajaran, dengan tujuan mempersiapkan anak dari satu generasi ke generasi selanjutnya, sampai menuju kedewasaan, hingga mereka menjadi anggota masyarakat yang berkarakter dan memiliki dampak bagi setiap generasi dalam kehidupan berbangsa dan bernegara. Untuk mencapai tujuan pembentukan dan pendidikan karakter perlu juga dipertimbangkan berbagai macam metode, ini bisa menjadi unsur-unsur sangat penting bagi sebuah usaha untuk pengembangan pembentukan karakter.

\section{b. Indikator Pembentukan Karakter}

Proses pembentukan karakter adalah suatu sistem penanaman nilai-nilai karakter pada anak yang meliputi pengetahuan, kesdaran atau kemauan dan untuk melaksanakan nilai-nilai. Menurut Lickona pendidikan karakter dapat diartikan sebagai upaya untuk membentuk kepribadian seseorang melalui pendidikan yang hasilnya terlihat dalam tindakan nyata seseorang berupa tingkah laku yang baik, jujur, bertanggung jawab, menghormati hak orang lain, kerja keras dan sebagainya. ${ }^{43}$ Mengingat banyaknya nilai-nilai yang harus dikembangkan dalam pembentukan karakter, menurut Megawangi, guru maupun pembina bisa mengklasifikasikan pendidikan karakter kedalam tiga komponen utama yaitu: ${ }^{44}$

- Keberagaman: terdiri dari nilai-nilai kekhususan hubungan dengan Tuhan, ketaatan dalam menjalankan ajaran agama, nilai baik dan keikhlasan, perbuatan baik, respons terhadap perbuatan baik dan buruk.

- Kemandirian: terdiri dari nilai-nilai harga diri, disiplin, etos kerja, rasa tanggung jawab, keberanian dan semangat, keterbukaan, pengendalian diri.

- Kesusilaan: terdiri dari nilai-nilai cinta dan kasih sayang, kebersamaan, kesetiakawanan, tolong menolong, tenggang rasa, hormat menghormati, kelayakan atau kepatuhan, rasa malu, kejujuran, pernyataan terima kasih dan permintaan maaf (rasa tahu diri).

Adapun beberapa indikator dari pembentukan karakter dijabarkan sebagai berikut:

1) Takut Akan Tuhan

Takut akan Tuhan berbeda dengan takut akan manusia. Ada banyak hal yang sering membuat manusia mengalami rasa takut seperti takut akan kegelapan. Takut akan kematian, takut akan ketinggian, takut akan kehilangan orang-orang yang dicintai dan banyak jenis ketakuatan lainnya. Takut akan Tuhan bukanlah seperti itu. Perintah yang sering kali diberikan kepada umat Allah dalam Alkitab Perjanjian Lama ialah "takut akan Allah" atau "takut akan Tuhan".

Menurut Welch, takut akan manusia adalah sesuatu yang kita lakukan secara alamiah. Semenjak kejatuhan manusia dalam dosa, takut akan manusia telah menjadi naluri manusia kita. Namun tragisnya, hati kita mempunyai mitra dalam mengembangkan kecendrungan berdosanya. Dunia beserta segala asumsinya yang tidak alkitabiah justru menguatkan kecenderungan untuk takut atau gentar kepada sesama manusia. ${ }^{45}$ Sedangkan takut akan Tuhan adalah kesadaran akan kekudusan, keadilan dan kebenaran-Nya sebagai pasangan terhadap kasih dan pengampunan-Nya, yaitu: mengenal Dia dan memahami sepenuhnya siapakah Dia (Ams. 2:5). Takut akan Tuhan berarti memandang Tuhan dengan keagungan dan penghormatan kudus serta menghormati-Nya sebagai Allah karena kemuliaan.

\footnotetext{
${ }^{43}$ T. Lickona, Character Development in Schools and Beyond(NewYork:Praeger, 1987), $253-$ 273. 2007)111.

${ }^{44}$ Megawangi, Ratna. Character Parenting Space,(Bandung: Publishing House Mizan

${ }^{45}$ Edward T. Welch, Ketika Manusia Dianggap Besar dan Allah Dianggap Kecil (Surabaya: Momentum Christian Literature, 2003), 79.
} 
Kekudusan, keagungan, dan kuasa-Nya yang besar (Flp. 2:12). ${ }^{46}$ Takut akan Tuhan adalah merasa gentar (ngeri) atau segan terhadap Allah Yang Mahatinggi, Mahamulia, Mahakudus dan Mahakuasa. Takut akan Tuhan merupakan ketakutan yang kudus, di mana sikap kita mempunyai dampak dari pengenalan orang percaya akan Allah yang hidup. ${ }^{47}$

Sebagai upaya untuk meningkatkan kesesuaian dan mutu pendidikan karakter siswa, maka dalam pembinaan pembentukan karakter juga termasuk dalam materi yang harus diajarkan dan dikuasai serta direalisasikan kepada siswa dalam kehidupan sehari-sehari, dengan belajar untuk mengaplikasikan rasa takut akan Tuhan yang terwujud dalam pikiran, sikap, perasaan, perkataan dan perbuatan berdasarkan norma-norma agama, hukum tata krama, budaya dan adat istiadat.

\section{2) Bertanggung Jawab}

Peran pembimbing atau pembina mempunyai peran yang penting yaitu senantiasa memberikan contoh teladan kepada anak didiknya. Selain itu, agar tercapainya pendidikan karakter yang dapat dilakukan oleh guru atau pembina adalah bekerja sama dengan para orang tua dan masyarakat untuk menyelaraskan penanaman pendidikan karakter di lingkungan sekolah dengan pendidikan karakter di lingkungan keluarga agar pendidikan karakter yang ditanamkan berjalan sesuai yang diharapkan.

Lickona berpendapat bahwasanya tanggung jawab adalah usaha yang dilakukan oleh individu untuk menjaga dirinya sendiri maupun menjaga diri orang lain sehinga ia dapat menjadi individu yang dapat menjalankan kewajibannya untuk ikut serta dalam kegiatan yang diselenggarakan di masyarakat sehingga terciptalah kehiduapan yang lebih baik lagi dengan masyarakat. ${ }^{48}$

Tangung jawab sangat berpengaruh dalam pendidikan karakter anak, dalam hal ini dibutuhkan penilaian untuk mengukur sejauh mana anak dapat mempunyai nilai-nilai karakter yang diharapkan tertanam. Dengan adanya penilaian, apabila anak belum mempunyai karakter yang baik sikap tanggung jawab merupakan karakter yang selayaknya ditanamkan. Karakter tanggung jawab merupakan suatu karakter yang harus dimiliki oleh anak agar menjadi pribadi yang bertanggung jawab di masa yang akan datang.

\section{3) Bersikap Jujur}

Bersikap jujur adalah sebuah sikap yang selalu berupaya menyesuaikan atau mencolok antara informasi dengan fenomena atau realitas. Menurut Rusyan, arti jujur dalam Bahasa Arab merupakan terjemahan dari kata shidiq yang artinya benar, dapat dipercaya. Dengan kata lain, jujur adalah perkataan dan perbuatan sesuai dengan kebenaran. Jujur juga disebut dengan benar, memberikan sesuatu yang benar atau sesuai dengan kenyataan. ${ }^{49}$ Sedangakan menurut Kamus Besar Bahasa Indonesia jujur artinya "lurus hati, tidak berbohong, tidak curang, tulus atau iklas". ${ }^{50}$ Dengan demikian dapat disimpulkan bahwa bersikap jujur adalah suatu tindakan yang sesuai dengan faktanya sehingga dapat dipercaya dan memberikan pengaruh bagi kesuksesan seseorang. Bersikap jujur itu akan terletak pada ucapan juga

\footnotetext{
${ }^{46}$ Alkitab Penuntun Hidup Berkelimpahan (Malang: Gandum Mas, 2000), 286.

${ }^{47}$ Ensikpopedia Alkitab Masa Kini Jilid II. (Jakarta: Yayasan Komunikasi Bina Kasih/ OMF
} 1995). 438-439. 2003), 3 .

\footnotetext{
${ }^{48}$ Thomas Lickona, The Fourth and Fifth RS, Volume 10 (Cortland: School of Education,
}

${ }^{49}$ A. Tabrani Rusyan, Pendidikan Budi Pekerti, (Jakarta: Inti Media Cipta Nusantara, 2006), 25.

${ }^{50}$ Muhamad Arifin bin Badri, Sifat Perniagaan Nabi, (Bogor: Pustaka Darul Ilmi, 2008), 76. 
terdapat pada perbuatan, sebagaimana seorang yang melakukan sesuatu perbuatan, tentu sesuai dengan yang ada pada batinnya. ${ }^{51}$

Guru atau pembina hendaknya memberikan pemahaman yang memadai tentang makna kejujuran, pemahaman mengapa seseorang mesti bersikap jujur, pemahaman bahwa kejujuran mesti diterapkan dalam kehidupan sehari-hari, pemahaman bahwasanya kejujuran tidak berhenti sebatas pemahaman yang dihafalkan, namun berlanjut pada tahap penghayatan dan pengalaman. Membentuk karakter jujur pada peserta didik memang tidak bisa dilakukan dengan sekadar menyampaikan materi apa adanya. Pihak pembina asrama harus menyediakan alat bantu yang dapat mendukung terciptanya iklim kejujuran pada dirinya.

\section{4) Disiplin dan Mampu Mengendalian Diri}

Siswa adalah orang yang terlibat langsung dalam dunia pendidikan. Dalam perkembanganya harus melalui proses belajar. Termasuk di dalamnya belajar mengenal diri, belajar mengenal orang lain, dan belajar mengenal lingkungannya. Ini dilakukan siswa agar siswa dapat mengetahui dan menempatkan posisinya di tengah-tengah masyarakat sekaligus mampu mengendalikan diri.

Sifat pengendalian diri harus ditumbuh kembangkan pada diri siswa. Pengendalian diri yang dimaksudkan adalah suatu kondisi di mana seseorang dalam perbuatannya selalu dapat menguasai diri sehingga tetap mengontrol diri dari berbagai keinginan yang terlalu meluapmeluap dan berlebihan-lebihan, berarti dalam sikap pengendalian diri tersebut terkandung keteraturan hidup dan kepatuhan akan segala peraturan. Hal yang sama dinyatakan oleh Tuhan dalam kebenaran firman-Nya mengenai penguasaan diri sebagai buah Roh adalah penyangkalan diri terhadap keinginan atau kesenangan yang jahat. Penguasaan diri bertolak belakang dengan dua perbuatan daging yang disebut terakhir (Gal. 5:21).

Pengendalian diri sendiri yang harus kita lakukan adalah: megendalikan diri kita sendiri di bawah pimpinan Roh Kudus. Penguasaan diri sebagai buah Roh adalah disiplin diri. Dengan kata lain, perbuatan siswa selalu berada dalam koridor disiplin dan tata tertib sekolah maupun asrama. Bila demikian, akan tumbuh rasa kedisiplinan siswa untuk mengikuti tiap-tiap peraturan yang berlaku di sekolah dan di asrama.

Menurut Nursisto, masalah kedisiplinan siswa menjadi sangat berarti bagi kemajuan sekolah. ${ }^{52}$ Demikian dapat dikaitkan juga di dalam kehidupan berasrama dengan aturan yang tertib akan selalu menciptakan proses pembelajaran yang baik. Sebaliknya, pada sekolah maupun asrama yang tidak tertib kondisinya jauh berbeda. Pelanggaran-pelanggaran yang terjadi sudah dianggap barang biasa dan untuk memperbaiki keadaan yang demikian tidaklah mudah. Hal ini diperlukan kerja sama dari pihak pembina dengan siswa untuk menjalankan setiap peraturan yang berlaku, sehingga berbagai jenis pelanggaran terhadap peraturan dan tata tertib asrama tersebut tidak terjadi.

Darmodihardjo mengatakan bahwa "seorang guru tidak akan efektif mengajar apabila ia sendiri tidak mengetahui apa yang menjadi keinginan siswa, dan seorang guru tidak akan hidup dengan norma Pancasila bila dia tidak meyakini dan mengahayatinya". Menciptakan kedisiplinan siswa bertujuan untuk mendidik siswa agar sanggup mengatur diri sendiri. Mereka dilatih untuk menguasai kemampuan, juga melatih siswa agar ia dapat mengatur dirinya sendiri. Demikian siswa dapat mengerti kelemahan atau kekurangnya ada pada

${ }^{51}$ Nurla Isna Aunilah, Panduan Menerapkan Pendidikan Karekter disekolah, (Yogyakarta: Laksana, 2011), 125.

${ }^{52}$ Nusisto, Peningkatan Prestasi Sekolah Mengangah: Acuan Siswa Pendidikan dan Orang Tua, (Jakarta: Insan Cendekia, 2002), 78. 
dirinya sendiri. Menanamkan kedisiplinan siswa merupakan tugas tenaga pendidik (guru) atau pembina asrama. Untuk menanamkan kedisiplinan siswa ini harus dimulai dari dalam diri guru dan pembina itu sendiri. Dengan demikian dapat mendisiplinkan, setiap siswa dan menciptakan kehidupan berasrama yang penuh dengan ketenangan, ketentraman, dan keharmonisan.

5) Mandiri

Peningkatan mutu pendidikan di sekolah berkaitan langsung dengan siswa sebagai anak didik dan guru sebagai pendidik. Dalam suatu proses pendidikan siswa yang tinggal di asrama memperoleh bimbingan, pengalaman, pengertian serta pandangan yang menyebabkan setiap mereka berpikir lebih maju. Pemberian bimbingan, kecakapan dan pengetahuan kepada siswa-siswa yang merupakan proses belajar mengajar itu dilakukan oleh guru atau pembina selama di sekolah demikian juga ketika berada di asrama dengan menggunakan metode tertentu.

Holstein mengemukakan bahwa "dengan mandiri, tidak berarti murid-murid belajar secara individualis, bahkan sebaliknya situasinya dibina untuk belajar kelompok dan setiap murid menjadi partner sesamanya". Siswa dengan kemandirian yang tinggi akan berusaha untuk mendapatkan dan menggunakan segala fasilitas dan sumber belajar dengan sebaikbaiknya. Sikap mandiri siswa dalam mengerjakan tugas harus dipupuk sedini mungkin, karena dengan sikap mandiri dapat menunjukkan inisiatif, berusaha untuk mengejar prestasi, mempunyai rasa percaya diri. ${ }^{53}$

Sikap mandiri sangat penting dimiliki oleh siswa agar dalam bersikap dan melaksanakan tugas tidak tergantung pada orang lain dan bertanggung jawab terhadap apa yang telah dikerjakannya. Untuk meningkatkan pendalaman materi pelajaran yang telah diberikan maka siswa dilatih dengan memberi tugas yang harus dikerjakan di sekolah maupun di rumah. Tugas-tugas yang diberikan guru sedapat mungkin dikerjakan oleh siswa secara mandiri untuk melatih pikiran siswa dalam memanfaatkan sumber belajar yang ada.

\section{6) Bekerjasama}

Kerjasama merupakan hal yang penting bagi kehidupan manusia, karena dengan kerjasama manusia dapat melangsungkan kehidupannya. Kerjasama juga menuntut interaksi antara beberapa pihak. Menurut Soekanto kerjasama merupakan suatu usaha bersama antara orang per orangan atau kelompok untuk mencapai tujuan tertentu. Pendapat tersebut sudah jelas mengatakan bahwa kerjasama merupakan bentuk hubungan antara beberapa pihak yang saling berinteraksi untuk mencapai tujuan bersama. ${ }^{54}$

Kerjasama dalam konteks pembelajaran yang melibatkan siswa, Huda menjelaskan lebih rinci yaitu, ketika siswa bekerja sama untuk menyelesaikan suatu tugas kelompok, mereka memberikan dorongan, anjuran, dan informasi pada teman sekelompoknya yang membutuhkan bantuan. ${ }^{55}$ Hal ini berarti dalam kerjasama, siswa yang lebih paham akan memiliki kesadaran untuk menjelaskan kepada teman yang belum paham.

Dari kedua pendapat di atas dapat disimpulkan bahwa kerjasama siswa dapat diartikan sebagai sebuah interaksi atau hubungan antara siswa dengan siswa dan siswa dengan guru atau pembina untuk mencapai tujuan dari suatu pembelajaran. Hubungan yang dimaksud

\footnotetext{
${ }^{53}$ Herman Holstein, Murid Belajar Mandiri, (Bandung: Remaja Rosda Karya 1986), 5.

${ }^{54}$ Soerjono Soekanto, Sosiologi Suatu Pengantar (Jakarta: Raja Grafindo Pesrsada 2006),66.

${ }^{55}$ Miftahul Huda, Cooperatiive Learning: Metode, Teknik, Struktur dan Modal Penerapan (Yogyakarta: Pustaka Pelajar 2011), 24-25).
} 
adalah hubungan yang dinamis yaitu, hubungan yang saling menghargai, saling peduli, saling membantu, dan saling memberikan dorongan sehingga tujuan pembelajaran tercapai. Tujuan pembelajaran tersebut meliputi perubahan tingkah laku, penambahan pemahaman, dan penyerapan ilmu pengetahuan.

Untuk meningkatkan kerjasama siswa perlu diajarkan keterampilan sosial. Hal ini dikarenakan dengan keterampilan sosial, nilai-nilai dalam kerjasama akan terinternalisasi dalam diri siswa dengan cara pembiasaan. Keterampilan sosial yang harus dimiliki siswa untuk meningkatkan kemampuan kerjasama siswa diungkapkan oleh Huda untuk mengkoordinasi setiap usaha demi mencapai tujuan kelompok, siswa harus: Saling mengerti dan percaya satu sama lain, berkomunikasi dengan jelas dan tidak ambigu, saling menerima dan mendukung satu sama lain, mendamaikan setiap perdebatan yang sekiranya melahirkan konflik.

\section{HASIL PENELITIAN}

Hasil uji hipotesis dapat dilihat sebagai berikut:

1. Uji Hipotesis Pertama

Hipotesis pertama dalam penelitian ini berbunyi: "Diduga tingkat pembinaan kehidupan berasrama di asrama Mahasiswa/i Sekolah Tinggi Teologi Kristus Alfa Omega Semarang berada dalam kategori sedang atau $\leq 70 \%$ "

$\mu_{0}=$ (Nilai Hipotesis) $\mathrm{x}$ (Mean Skor Ideal)

Keterangan:

Nilai hipotesis $\quad=75 \%$

Mean skor ideal $=\{($ skor tertinggi tiap item $) \mathrm{x}$ (jumlah item variable $\mathrm{X})$

$\mathrm{x}$ (jumlah responden) $\}: \mathrm{N}$

$=(5 \times 19 \times 37): 37$

$=3515: 37$

$=95$

$\mu_{0} \quad=(75 \%) \times 75$

$=56,25$

Jadi nilai yang dihipotesis $\left(\mu_{0}\right)$ dari variabel tingkat pembinaan kehidupan berasrama di asrama Mahasiswa/i Sekolah Tinggi Teologi Kristus Alfa Omega Semarang adalah 75\% atau sama dengan 56,25. Selanjutnya dilakukan perhitungan nilai rata-rata empiris (mean skor empiris), adapun hasilnya seperti di bawah ini:

Mean skor empiris $\quad=($ Total Skor Empiris $):$ jumlah responden $)$

$$
\begin{aligned}
& =2115: 37 \\
& =57,162
\end{aligned}
$$

Berdasarkan perbandingan nilai $\mu_{0}$ adalah $70 \%$ atau sama dengan 52,5 , sedangkan mean skor empiris adalah 57,162. Dengan demikian diketahui bahwa nilai hipotesis $\left(\mu_{0}\right) 70 \%$ atau sama dengan 52,5 tidak sama dengan nilai skor empiris yaitu 57,162. Dengan arti lain nilai skor empiris terbukti lebih besar dari nilai hipotesis $\left(\mu_{0}\right)$. Jadi hipotesis yang berbunyi bahwa: "Diduga tingkat pembinaan kehidupan berasrama di asrama Mahasiswa/i Sekolah Tinggi Teologi Kristus Alfa Omega Semarang berada dalam kategori sedang atau $\leq 70 \%$ " di tolak. 
Selanjutnya untuk mengetahui nilai tingkat pembinaan kehidupan berasrama di asrama Mahasiswa/i Sekolah Tinggi Teologi Kristus Alfa Omega Semarang dapat dilakukan dengan cara berikut:

Harga \% Variabel $X=\frac{\Sigma \text { Skor Empiris }}{\Sigma \text { Skor Ideal }} \times 100 \%$

Keterangan:

Total skor empiris $\quad=$ Skor total data variabel $\mathrm{X}=2115$

Total skor ideal

$=($ skor tertinggi tiap item $) \mathrm{x}$ (jumlah item variable $\mathrm{X})$

$\mathrm{x}$ (jumlah responden)

$=5 \times 15 \times 37$

$=2775$

Harga \% Variabel X $\quad=(2115: 2775) \times 100 \%$

$=76,216 \%$

Berdasarkan perhitungan di atas diperoleh nilai persentase tingkat pembinaan kehidupan berasrama di asrama Mahasiswa/i Sekolah Tinggi Teologi Kristus Alfa Omega Semarang selanjutnya nilai ini akan diinterpretasi dengan tabel interpretasi hipotesis di bawah ini:

Pedoman untuk Interpretasi makna Persentase Deskriptif ${ }^{56}$
\begin{tabular}{|c|l|}
\hline Prosentase & \multicolumn{1}{|c|}{ Makna } \\
\hline $0-20$ & Sangat Rendah \\
\hline $21-40$ & Rendah \\
\hline $41-60$ & Sedang \\
\hline $61-80$ & Tinggi \\
\hline $81-100$ & Sangat Tinggi \\
\hline
\end{tabular}

Berdasarkan tabel di atas maka nilai tingkat pembinaan kehidupan berasrama di asrama Mahasiswa/i Sekolah Tinggi Teologi Kristus Alfa Omega Semarang dengan nilai $76,216 \%$ yang berada pada persentase tinggi yaitu antara (61-80).

2. Uji Hipotesis Kedua

Hipotesis kedua dalam penelitian ini berbunyi: "Diduga tingkat pembentukaan karakter Mahasiswa/i Sekolah Tinggi Teologi Kristus Alfa Omega Semarang berada dalam kategori sedang atau $\leq 75 \%$ "

$\mu_{0}=$ (Nilai Hipotesis) $\mathrm{x}$ (Mean Skor Ideal)

Keterangan:

Nilai hipotesis $\quad=70 \%$

Mean skor ideal $=\{($ skor tertinggi tiap item $) \times($ jumlah item variable $\mathrm{X})$

$\mathrm{x}$ (jumlah responden) $\}: \mathrm{N}$

$=(5 \times 15 \times 37): 37$

${ }^{56}$ Gideon Joshua, Penelitian Terhadap Hubungan Persepsi Gembala Sidang tentang Pemimipin Hamba dengan Keberhasilan Memimpin Gereja Lokal (Semarang: 2009), 113. 


$$
\begin{aligned}
& =2775: 37 \\
& =75 \\
& \mu_{0}=(\mathbf{7 0 \%}) \times 75 \\
& =56,25
\end{aligned}
$$

Jadi nilai yang dihipotesis $\left(\mu_{0}\right)$ dari variabel tingkat tingkat pembentukaan karakter Mahasiswa/i Sekolah Tinggi Teologi Kristus Alfa Omega Semarang adalah 75\% atau sama dengan 52,5. Selanjutnya dilakukan perhitungan nilai rata-rata empiris (mean skor empiris), adapun hasilnya seperti di bawah ini:

Mean skor empiris $\quad=$ (Total Skor Empiris) $:$ (jumlah responden $)$

$$
\begin{aligned}
& =2870: 37 \\
& =77,567
\end{aligned}
$$

Berdasarkan perbandingan nilai $\mu_{0}$ adalah $75 \%$ atau sama dengan 56,25 , sedangkan mean skor empiris adalah 77,567. Dengan demikian diketahui bahwa nilai hipotesis $\left(\mu_{0}\right) 75 \%$ atau sama dengan 56,25 tidak sama dengan nilai skor empiris yaitu 77,567. Dengan arti lain nilai skor empiris terbukti lebih besar dari nilai hipotesis $\left(\mu_{0}\right)$. Jadi hipotesis yang berbunyi bahwa: "Diduga tingkat pembentukaan karakter Mahasiswa/i Sekolah Tinggi Teologi Kristus Alfa Omega Semarang berada dalam kategori sedang atau $\leq 75 \%$ " ditolak.

Selanjutnya untuk mengetahui nilai tingkat pembentukaan karakter Mahasiswa/i Sekolah Tinggi Teologi Kristus Alfa Omega Semarang dapat dilakukan dengan cara berikut:

$$
\text { Harga } \% \text { Variabel } X=\frac{\Sigma \text { Skor Empiris }}{\Sigma \text { Skor Ideal }} \times 100 \%
$$

Keterangan:

Total skor empiris

$=$ Skor total data variabel $\mathrm{X}=2870$

Total skor ideal

$$
\begin{aligned}
= & (\text { skor tertinggi tiap item }) \times(\text { jumlah item variable } \mathrm{X}) \\
& \mathrm{x} \text { (jumlah responden }) \\
= & 5 \times 19 \times 37 \\
= & 3515
\end{aligned}
$$

Harga \% Variabel X

$$
\begin{aligned}
& =(2870: 3515) \times 100 \% \\
& =81,65 \%
\end{aligned}
$$

Berdasarkan perhitungan di atas diperoleh nilai persentase tingkat pembentukaan karakter Mahasiswa/i Sekolah Tinggi Teologi Kristus Alfa Omega Semarang selanjutnya nilai ini akan diinterpretasi dengan tabel interpretasi hipotesis di bawah ini:

Pedoman untuk Interpretasi makna Persentase Deskriptif ${ }^{57}$
\begin{tabular}{|c|l|}
\hline Prosentase & \multicolumn{1}{|c|}{ Makna } \\
\hline $0-20$ & Sangat Rendah \\
\hline $21-40$ & Rendah \\
\hline $41-60$ & Sedang \\
\hline $61-80$ & Tinggi \\
\hline $81-100$ & Sangat Tinggi \\
\hline
\end{tabular}

\footnotetext{
${ }^{57}$ Gideon Joshua, Penelitian Terhadap Hubungan Persepsi Gembala Sidang tentang Pemimipin Hamba dengan Keberhasilan Memimpin Gereja Lokal (Semarang: 2009), 113.
} 
Berdasarkan tabel di atas maka nilai tingkat pembentukaan karakter Mahasiswa/i Sekolah Tinggi Teologi Kristus Alfa Omega Semarang dengan nilai 81,65\% yang berada pada prosentasi sangat tinggi yaitu antara (81-100).

\section{Uji Hipotesis Ketiga}

Hipotesis kedua dalam penelitian ini berbunyi: "Diduga terdapat pengaruh yang positif dan dalam kategori sedang antara pembinaan kehidupan berasrama terhadap pembentukan karakter Mahasiswa Sekolah Tinggi Teologi Kristus Alfa Omega Semarang." Merupakan hipotesis asosiatif atau korelasional (melihat pengaruh hubungan antara variabel independen dengan variabel dependen). Sehingga uji hipotesisnya akan dilakukan dengan menggunakan korelasi Product Moment dengan menggunakan bantuan program computer SPSS 23. Adapun beberapa analisis yang dilakukan dalam uji hipotesis asosiatif (korelasional) yaitu sebagai berikut:

a. Koefisian Korelasi

Koefisien korelasi digunakan untuk melihat keeratan hubungan antara variabel pembinaan kehidupan berasrama $(\mathrm{X})$ terhadap variabel pembentukan karakter Mahasiswa Sekolah Tinggi Teologi Kristus Alfa Omega Semarang (Y).

Hasil Perhitungan korelasi sederhana antara X dengan Y

Model Summary

\begin{tabular}{|l|r|r|r|r|}
\hline Model & $\mathrm{R}$ & R Square & $\begin{array}{c}\text { Adjusted R } \\
\text { Square }\end{array}$ & $\begin{array}{c}\text { Std. Error of } \\
\text { the Estimate }\end{array}$ \\
\hline 1 & $.441^{\mathrm{a}}$ & .195 & .172 & 7.171 \\
\hline
\end{tabular}

a. Predictors: (Constant), SkortotalX

Berdasarkan tabel analisis koefisien korelasi (R) di atas, diperoleh nilai koefisien korelasi (R) sebesar 0,441 dan bernilai positif, yang memiliki arti bahwa terdapat pengaruh yang positif dan dalam kategori sedang antara pembinaan kehidupan berasrama terhadap pembentukan karakter Mahasiswa Sekolah Tinggi Teologi Kristus Alfa Omega Semarang adalah sebesar 0,441 dan bernilai positif.

Selanjutnya untuk mengetahui makna koefisien korelasi (R) antara variabel pembinaan kehidupan berasrama (X) terhadap variabel pembentukan karakter Mahasiswa Sekolah Tinggi Teologi Kristus Alfa Omega Semarang (Y) tersebut, maka nilai yang diperoleh dibandingkan dengan tabel pedoman interpretasi koefisien korelasi sebagai berikut:

Pedoman untuk memberikan Interpretasi Koefisien Korelasi

\begin{tabular}{|c|c|}
\hline Interval koefisien & Makna \\
\hline $0,00-0,199$ & Sangat rendah \\
\hline $0.20-0,399$ & Rendah \\
\hline $0,40-0,599$ & Sedang \\
\hline $0,60-0,799$ & Kuat \\
\hline $0,80-1,00$ & Sangat Kuat \\
\hline
\end{tabular}

Berdasarkan tabel di atas dan nilai koefisien korelasi yang diperoleh yaitu sebesar 0,441 berada pada kategori sedang yaitu 0,40-0,599. Sehingga hubungan antara variabel pembinaan kehidupan berasrama (X) terhadap variabel pembentukan karakter Mahasiswa/i Sekolah Tinggi Teologi Kristus Alfa Omega Semarang (Y) berada pada kategori sedang. Dengan demikian maka hipotesis ketiga dalam penelitian ini yang berbunyi: "Diduga terdapat 
pengaruh yang positif dan dalam kategori sedang antara pembinaan kehidupan berasrama terhadap pembentukan karakter Mahasiswa/i Sekolah Tinggi Teologi Kristus Alfa Omega Semarang" diterima. Sebab berdasarkan analisis data diperoleh hubungan yang sedang yaitu 0,441 atau berada pada kategori sedang $(0,40-0,599)$.

b. Koefisian Determinasi

Koefisien determinasi digunakan untuk mengetahui kontribusi atau sumbangsih variabel pembinaan kehidupan berasrama $(\mathrm{X})$ terhadap variabel pembentukan karakter Mahasiswa/i Sekolah Tinggi Teologi Kristus Alfa Omega Semarang (Y). Hasil analisis koefisien determinasi dapat dilihat pada tabel di bawah ini:

Koefisien Determinasi antara Variabel X terhadap Variabel Y

\begin{tabular}{|l|r|r|r|r|}
\hline Model & $\mathrm{R}$ & R Square & $\begin{array}{c}\text { Adjusted R } \\
\text { Square }\end{array}$ & $\begin{array}{c}\text { Std. Error of } \\
\text { the Estimate }\end{array}$ \\
\hline 1 & $.441^{\mathrm{a}}$ & .195 & .172 & 7.171 \\
\hline
\end{tabular}

a. Predictors: (Constant), SkortotalX

Berdasarkan tabel di atas diperoleh nilai koefisien determinasi yang berada pada $\mathrm{R}$ Square sebesar 0,195 atau 19,5\%. Artinya kontribusi atau sumbangsih variabel pembinaan kehidupan berasrama (X) terhadap variabel pembentukan karakter Mahasiswa/i Sekolah Tinggi Teologi Kristus Alfa Omega Semarang (Y) dalam penelitian ini sebesar 0,195 atau 19,5\% sementara faktor lain sebesar $80,5 \%$ bersumber dari hal-hal di luar variabel yang diteliti dalam penelitian ini.

c. Persamaan garis linier sederhana

Persamaan garis linier sederhana dinyatakan dengan rumus $\mathrm{Y}=\mathrm{a}+\mathrm{bX}$. Adapun hasil persamaan garis linier sederhana peroleh dari tabel di bawah ini:

\begin{tabular}{|c|c|c|c|c|c|c|}
\hline & & \multicolumn{3}{|c|}{ Coefficients $^{\mathrm{a}}$} & \multirow[b]{3}{*}{$\mathrm{t}$} & \multirow[b]{3}{*}{ Sig. } \\
\hline \multirow{2}{*}{\multicolumn{2}{|c|}{ Model }} & \multicolumn{2}{|c|}{ Unstandardized Coefficients } & $\begin{array}{l}\text { Standardized } \\
\text { Coefficients }\end{array}$ & & \\
\hline & & B & Std. Error & Beta & & \\
\hline 1 & (Constant) & 53.117 & 8.486 & & 6.259 & .000 \\
\hline & SkortotalX & .428 & .147 & .441 & 2.909 & .006 \\
\hline
\end{tabular}

a. Dependent Variable: Skor_Y

Berdasarkan tabel di atas diperoleh nilai a sebesar 53,117 dan nilai b sebesar 0,428 maka persamaan garis linier sederhananya dapat digambarkan sebagai berikut:

$\mathrm{Y}=\mathrm{a}+\mathrm{bX}$

$\mathrm{Y}=53,117+0,428 \mathrm{X}$

Berdasarkan hasil persamaan garis linier sederhana di atas dapat dinyatakan bahwa setiap perbaikan variabel pembinaan kehidupan berasrama (X) meningkat satu kali maka variabel pembentukan karakter Mahasiswa/i Sekolah Tinggi Teologi Kristus Alfa Omega Semarang (Y) akan meningkat sebesar 0,428 dari kondisi sekarang. 


\section{E. KESIMPULAN}

Pada bagian ini peneliti akan menyampaikan kesimpulan yang diperoleh melalui penelitian dan analisis data dalam penelitian ini.

1. Uji Hipotesis Pertama

Hipotesis pertama dalam penelitian ini berbunyi: "Diduga tingkat pembinaan kehidupan berasrama di asrama Mahasiswa/i Sekolah Tinggi Teologi Kristus Alfa Omega Semarang berada dalam kategori sedang atau $\leq 70 \%$ " ditolak. Nilai yang diperoleh adalah $76,216 \%$ yang pada tabel pedoman untuk interpretasi makna persentase deskriptif berada pada kategori tinggi. Sehingga dapat disimpulkan bahwa tingkat pembinaan kehidupan berasrama di asrama Mahasiswa/i Sekolah Tinggi Teologi Kristus Alfa Omega Semarang tinggi.

2. Uji Hipotesis Kedua

Hipotesis kedua dalam penelitian ini berbunyi: "Diduga tingkat pembentukan karakter Mahasiswa/i Sekolah Tinggi Teologi Kristus Alfa Omega Semarang berada dalam kategori sedang atau $\leq 75 \%$ " ditolak sebab nilai yang diperoleh sebesar $81,65 \%$ yang pada tabel pedoman untuk interpretasi makna persentase deskriptif berada pada kategori tinggi. Sehingga dapat disimpulkan bahwa tingkat pembentukan karakter Mahasiswa/i Sekolah Tinggi Teologi Kristus Alfa Omega Semarang tinggi.

\section{Uji Hipotesis Ketiga}

Hipotesis kedua dalam penelitian ini berbunyi: "Diduga terdapat pengaruh yang positif dan dalam kategori sedang antara pembinaan kehidupan berasrama terhadap pembentukan karakter Mahasiswa/i Sekolah Tinggi Teologi Kristus Alfa Omega Semarang" diterima sebab nilai koefisien korelasi yang diperoleh sebesar 0,441 yang berada pada kategori sedang dan berbentuk positif. Dengan persamaan garis linier sederhananya yaitu; $Y=53,117+0,428 \mathrm{X}$. Artinya setiap perbaikan variabel pembinaan kehidupan berasrama $(\mathrm{X})$ meningkat satu kali maka variabel pembentukan karakter Mahasiswa/i Sekolah Tinggi Teologi Kristus Alfa Omega Semarang (Y) akan meningkat sebesar 0,428 dari kondisi sekarang.

\section{DAFTAR PUSTAKA}

Agus Wibowo. Pendidikan Karakter:Strategi Membangun Karakter Bangsa Berpradaban. Yogyakarta: Pustaka Pelajar 2012.

Andreas Bambang Subagyo. Pengantar Riset Kualitatif dan Kuantitatif. Bandung: Yayasan Kalam Hidup, 2001.

Asep Saepul H dan E Bahruddin. Metode Penelitian Kuantitatif APlikasi Dalam Pendidikan. Yogyakarta: Deepublish, 2014.

Brian J. Bailey. Roh Kudus Sang Penghibur. Jakarta: Voice of Hope, 2015.

C. Marvin Pate, Teologi Paulus Tentang Kristologi, Seteriologi, Antropologi, Pneumatologi, Eklesiologi, Eskatologi. Malang: Gandum Mas, 2004.

Edward T. Welch. Ketika Manusia Dianggap Besar dan Allah Dianggap Kecil. Surabaya: Momentum Christian Literature, 2003.

Enung Fatimah. Psikologi Perkembangan. Bandung: CV Pustaka Setia 2006.

Enung Fatimah. Psikologi Perkembangan. Bandung: CV Pustaka Setia, 2006.

H. M Arifin, Hubungan Timbal Balik Pendidikan Agama (Jakarta: Bulan Bintang 1976.

Hendriati Agustiani. Psikologi Perkembangan. Bandung: PT Refika Aditama, 2006.

Herman Ridderbos. Paulus Pemikiran Utama Theologinya. Surabaya: Momentum, 2010.

Husaini Usman \& Purnomo Setiady Akbar. Metodologi Penelitian Sosial. Jakarta: PT. Bumi Aksara, 2008. 
Irna M. Lapindus. Kamus Umum Bahasa Indonesia. Jakarta: Balai Pustaka, 1982.

John Kingsley Alley. Holy Community. Jakarta: Metanoia Publishing, 2010.

Jonathan Sarwono. Metode Penelitian Kuantitatif dan Kualitatif. Yogyakarta: Graha Ilmu, 2006.

Jonathan Sarwono. Metode penelitian Kuantitatif dan Kualitatif. Yogjakarta: Grahallmu, 2006.

Joyce Meyer. The Power of Simple Prayer. Jakarta: Imanuel, 2010.

Kusmintardjo, Pengelolaan Layanan Khusus di Sekolah, Jilid I. Malang: IKIP 1992.

Kusmintardjo. Penyelengaraan Pelatihan Dengan Sistem Asrama (Boarding School, Jilid II. Malang: FIP UM 1992.

M. Buchori. Psikologi Pendidikan. Jakarta: Aksara Baru 1982.

Mangunharjana. Pembinaan: arti dan metodeknya. Jogyakarta: Kanisius, 1986.

Masnur Muslich. Pendidikan Karakter Menjawan Tantangan Krisis Multimdimensional. Jakarta: Bumi Akasra. 2011.

Megawangi, Ratna. Character Parenting Space. Bandung: Publishing House Mizan 2007.

Miftahul Huda. Cooperatiive Learning: Metode, Teknik, Struktur dan Modal Penerapan. Yogyakarta: Pustaka Pelajar 2011.

Mochamad Sajoto. Pembinaan Kondisi Fisik Dalam Olahraga. Jakarta: Pustaka Kartini. 1995.

Modjiono. Belajar dan Pembelajaran. Jakarta: Rineka Cipta, 1992.

Muhamad Arifin bin Badri. Sifat Perniagaan Nabi. Bogor: Pustaka Darul Ilmi, 2008.

Murnir. Kultur Asrama Berbasis Sekolah Pembinaan Karakter. Jakarta: LP3ES 1990.

Nusisto. Peningkatan Prestasi Sekolah Mengangah: Acuan Siswa Pendidikan dan Orang Tua. Jakarta: Insan Cendekia, 2002.

Rusli Ibrahim. Landasan Psikologi Pendidikan Jasmani Di Sekolah. Jakarta: Balai Pusataka 2001.

Singgih D. Gunasa \& Yuli Singgih D. Gunasa, Psikologi Praktis, Anak Remaja dan Kelurga. Jakarta: BPK Gunug Mulia, 2011.

Soejono Soekanto. Kamus Sosiologi. Jakarta: Rajawali Pres. 1993.

Soerjono Soekanto. Sosiologi Suatu Pengantar. Jakarta: Raja Grafindo Pesrsada 2006.

Sri Lestari. Psikologi Keluarga Penanaman Niliai dan Penanganan Konflik dalam Keluarga. Jakarta: Kencana, 2013.

Sugiono. Metode Penelitian Pendidikan (Bandung: Alfa Beta, 2010), 288.

Sugiyanto. Kamus Besar Bahasa Indonesia. Jakarta: Balai Pustaka. 1996.

T. Lickona. Character Development in Schools and Beyond. NewYork:Praeger, 1987.

Tabrani Rusyan. Pendidikan Budi Pekerti. Jakarta: Inti Media Cipta Nusantara, 2006.

Thomas Lickona. Charater Matter. Jakarta: Bumi Aksara, 2012.

Thomas Lickona. The Fourth and Fifth RS, Volume 10. Cortland: School of Education, 2003.

W.A. Gerungan. Psikkologi Sosial (Bandung: Eresoo. 1978).

Zubaedi. Desain Pendidikan Karakter Konsepsi dan Aplikasinya daam Dunia Pendidikan.

Jakarta: Kencana, 2012. 